University of Puget Sound

Sound Ideas

All Faculty Scholarship

Faculty Scholarship

Winter 1982

\title{
Unregenerate Doings: Selflessness and Selfishness in New Divinity Theology
}

William Breitenbach

University of Puget Sound, wbreitenbach@pugetsound.edu

Follow this and additional works at: http://soundideas.pugetsound.edu/faculty_pubs

\section{Citation}

Breitenbach, William. "Unregenerate Doings: Selflessness and Selfishness in New Divinity Theology." American Quarterly. 34.5 (1982): 479-502. Print.

This Article is brought to you for free and open access by the Faculty Scholarship at Sound Ideas. It has been accepted for inclusion in All Faculty Scholarship by an authorized administrator of Sound Ideas. For more information, please contact soundideas@pugetsound.edu. 


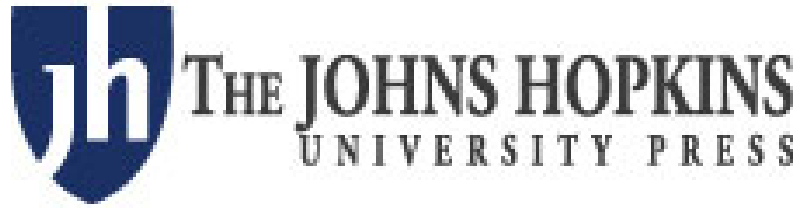

Unregenerate Doings: Selflessness and Selfishness in New Divinity Theology Author(s): William Breitenbach

Source: American Quarterly, Vol. 34, No. 5 (Winter, 1982), pp. 479-502

Published by: The Johns Hopkins University Press 


\title{
UNREGENERATE DOINGS: SELFLESSNESS AND SELFISHNESS IN NEW DIVINITY THEOLOGY
}

\author{
WILLIAM BREITENBACH
}

University of Puget Sound

ELIJAH PARISH WAS PLAYING POLONIUS. THE CONGREGATIONAL MINISTER OF Byfield, Massachusetts, admonished his son to consider the "vast importance" of sound preaching when he chose his place of residence. For his part, the elder Parish solemnly declared, he "would rather sit under the most ordinary preacher, than attend a minister of wrong principles, possessing the most profound genius and the most powerful eloquence."1

His fatherly advice seems unobjectionable enough. Yet Reverend Parish was a Hopkinsian, a proponent of the theological system set forth by Samuel Hopkins, the disciple of Jonathan Edwards. The Hopkinsian (or New Divinity) theologians, who flourished in New England during the second half of the eighteenth century and the first half of the nineteenth century, were infamous for their belief that sinners could perform no acceptable duty, not even in such actions as praying or Bible reading. Why then should Parish concern himself about the quality of the preaching that people heard, when he and his fellow New Divinity ministers claimed that the unconverted did nothing but sin when they heard it?

To their critics, the Hopkinsians' proposition seemed to encourage sinners to "neglect or abuse . . the prescribed means of grace." To Ezra Stiles, the "uncouth, venemous \& blasphemous" idea implied that an "Unconverted Man had better be killing his father \& mother than praying for convert[in]g

'William B. Sprague, comp. and ed., Annals of the American Pulpit; or Commemorative Notices of Distinguished American Clergymen of Various Denominations, from the Early Settlement of the Country to the Close of the Year Eighteen hundred and fifty-five (New York: Robert Carter and Brothers, 1859), II, 271.

${ }^{2}$ Moses Hemmenway, Seven Sermons, on the Obligation and Encouragement of the Unregenerate, to Labour for the Meat which Endureth to Everlasting Life (Boston: Kneeland and Adams, 1767), 196. 
Grace. ${ }^{\prime 3}$ Luckily, opponents noted, New Divinity preachers like Parish had a way of ignoring the obnoxious doctrine in their own lives. They compelled their wicked children to pray and rejoiced when their dissolute neighbors flocked to public worship. Yet even though the Hopkinsians partially redeemed their imperfect principles by their inconsistent practice, their adversaries warned that they professed an offensive doctrine: it seemed unevangelical at best and anarchical at worst to deny the value of sinners' best efforts.

The New Divinity position on unregenerate doings has been much criticized and little understood. The doctrine emerged during the mid-eighteenth century in response to the challenges facing New England Calvinism. By the 1740s and 1750s Arminians, both Anglican and Congregational, were attacking the "arbitrary" tenets of Calvinism, in particular the idea that God bestowed saving grace without any reference to the endeavors of the unconverted. Accusing Calvinists of preaching a creed that debilitated morality, Arminian critics maintained that God gave grace to sinners who strove for it.

Calvinists responded with explanations of how God administered his conditional covenant with men. They agreed with the Arminians that the Scriptures contained promises, that it was the duty of sinners to seek grace in the use of means, that saving grace was ordinarily dispensed through means, that sinners had encouragements in their strivings, and that these encouragements increased in proportion to the sinners' diligence. Yet the Calvinists parted ways with the Arminians on the question of whether there were promises of special grace made upon condition of unregenerate endeavors. True, God's covenant of grace was a conditional one, but the promise was that God would save those who had faith in Christ, and that faith was a free and gracious gift of God, not a reward for human effort. Sinners could not earn justification by their own righteousness, for there was no moral excellency in their works.

Still, because they did not want cutthroats and fornicators defending wickedness by spouting the doctrine of free grace, Calvinists carefully explained that their theology did not "cut the Sinew" of sinners' efforts. For one thing, duties like prayer were "materially good" though they had no "formal Goodness" or "true Morality." For another thing, the encouragements under which the unregenerate labored provided strong motives for exertion. Nudging the idea of encouragement until it teetered on the brink of becoming a promise, Calvinists persuaded themselves "that not a single Instance will be found of any Sinner in the Day of Judgment able to stand

${ }^{3}$ Ezra Stiles, The Literary Diary of Ezra Stiles, D.D., LL.D., ed. Franklin Bowditch Dexter (New York: Charles Scribner's Sons, 1901), II, 505, 115. 
forth, and plead in Truth, Lord, I did my best Endeavour to the very last ... but after all was deny'd." 4

The ticklish problem facing the Calvinists was to preach free grace without provoking immorality. They found their task complicated by the injudicious zeal of some of their Calvinist brethren. In New England, the Great Awakening was generally interpreted by its supporters as a divine vindication of those who preached the doctrine of justification by faith in its Calvinistic purity. Yet the Great Awakening had also hatched some extreme New Lights, bellicose sectarians like Andrew Croswell and James Davenport, who so exalted Christ's imputed righteousness and so vilified man's polluted works that they seemed intent upon resurrecting the antinomianism of Anne Hutchinson's day.

These New England extremists were part of a broader reactionary movement within eighteenth-century Calvinism, which responded to the Enlightenment by proclaiming increasingly antinomian positions on the doctrine of justification. Participants in this movement shared a conviction that the preservation of Calvinism rested on a repudiation of any hint of works righteousness. They complained that many of the orthodox did not adequately emphasize the sufficiency of Christ. They warned against substituting a reliance on human activity or the means of grace for faith in Christ. Thus, the extreme New Lights of New England could draw upon (and reprint) the works of intellectually respectable British theologians of an "antinomian" cast: Walter Marshall, Thomas Boston, Ralph Erskine, Ebenezer Erskine, Robert Sandeman, William Cudworth, and James Hervey.

By the early 1760s New England mainstream or "Old" Calvinists were doubly beleaguered. On the one flank were the Arminians, attacking them for making too little of morality and for promoting fatalism and licentiousness. On the other flank, antinomian enthusiasts assailed them for mongrelizing doctrine and for making too many concessions to human works. The Old Calvinists' problems were just beginning, for in 1765 Samuel Hopkins published his Enquiry concerning the Promises of the Gospel; Whether any of them are made to the exercises and doings of persons in an Unregenerate State. ${ }^{5}$ Thereafter the Old Calvinists were triply beleaguered.

Hopkin's point was simple enough. He responded to the Arminians by stating flatly that before regeneration everything done by a sinner was totally

${ }^{4} \mathrm{~J}$ edidiah Mills, A Vindication of Gospel-Truth, and Refutation of some dangerous Errors, In Relation to that important Question, Whether there be Promises of the Bestowment of special Grace, made in Scripture to the Unregenerate, on Condition of any Endeavours, Strivings, or Doings of theirs whatsoever? (Boston: Rogers and Fowle, 1747), 75, 45, 77.

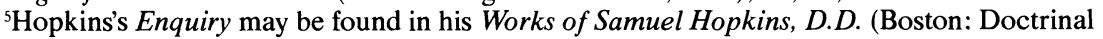
Tract and Book Society, 1852), III. 
wicked and unacceptable to God. Moreover, while the sinner remained unregenerate, the more he used the means of grace, the more he aggravated his guilt. Yet Hopkins was not just another antinomian reactionary. In fact, his arguments contained an implicit attack on antinomian passivity. He claimed that sinners had an ability to perform God's commands. Accordingly, the unconverted were to be exhorted to immediate repentance.

Hopkin's formulation managed to offend just about everyone who had previously considered the matter. The immediate consequence of his publication was a paper war-fiercest in the 1760s and 1770s, but warmly pressed well into the nineteenth century - that created and consolidated the New Divinity party. The ultimate consequence was the transformation of Calvinist theology and religious experience in New England.

The inspiration for Hopkins's New Divinity came from Jonathan Edwards's treatise on the will. Edwards's aim in that work had been to demonstrate "that God's moral government over mankind, his treating them as moral agents ... is not inconsistent with a determining disposal of all events." He set out to prove, in short, that one could be voluntary and accountable, even though acting under necessity.

Edwards began by stating that every volition of the will (which he also called the heart) expressed an inclination, preference, or desire of the person doing the choosing. A person never willed contrary to the prevailing inclination of his soul: he never chose what he did not prefer, and he preferred and chose that which appeared to be the greatest good. Thus the will could be said to be determined by the strongest motive, the strength of which arose from a combination of subjective and objective circumstances.

Edwards then analyzed the meaning of liberty, which he characterized as a person's power to do as he pleased. A man was free if he was under no physical "hindrance or impediment in the way of doing, or conducting in any respect, as he wills." Accordingly, all voluntary acts were by definition unquestionably free. Nor was a person's liberty affected by any consideration of what caused him to choose to do as he did. It was enough that the choice was voluntary.

To this explanation of the workings of the will, Edwards applied a distinction between two kinds of necessity - natural necessity and moral necessity. Natural necessity referred to "such necessity as men are under through the force of natural causes." An event naturally necessary would occur in spite of the choices or preferences of a person's will. Natural necessity thus involved some physical hindrance to voluntary action. Since something extrinsic to the will deprived the individual of liberty to act voluntarily, he was excused from accountability for that event. 
But there was another kind of necessity that did not excuse. Edwards defined moral necessity as the certainty that arose from the potency of "moral causes, such as habits and dispositions of the heart, and moral motives and inducements." Whereas natural necessity connected natural, involuntary causes and effects, moral necessity connected moral, voluntary ones. Nevertheless, Edwards insisted, moral necessity could be every bit as absolute as natural necessity.

Unlike natural necessity, however, moral necessity did not overpower the will. Edwards observed that no "opposition, or contrary will and endeavor, is supposable in the case of moral necessity; which is a certainty of the inclination and will itself; which does not admit of the supposition of a will to oppose and resist it." ${ }^{\circ}$ One Edwardsean drew the distinction between the two necessities in this manner: "If I should put you out of my house in spite of every effort you could make to oppose me, because I was the strongest man, I should say you went out by a natural necessity; - but if you went out of your own free choice, the event would prove there was a moral necessity, though you acted with an entire freedom; and in this case, there is no natural necessity."

As the example indicates, moral necessity was in no way incompatible with liberty as Edwards had defined it. Under natural necessity, a person had a physical inability to act as he pleased, but under moral necessity, his inability was nothing more than his disinclination to do something. Moral inability was a "will not" so strong that it became a "cannot." Of course, such unwillingness neither deprived the individual of his freedom to act voluntarily nor nullified his accountable moral agency.

Edwards's argument allowed him to preserve necessity without impairing liberty. Since the Fall, man had a habitual preference for sin. He had a moral inability to be holy because he lacked any inclination to choose the good. Yet despite this morally necessary depravity, he was a free agent, possessed of all the liberty he could possibly enjoy. After all, he was voluntary in his sinfulness: he loved it, preferred it, and chose it.

Edwards gave Calvinists grounds for exhorting sinners and grounds for blaming them. Sinners were naturally able to do their duty, if only they were willing to do it. The problem, of course, was that they always preferred to sin. Still, the moral necessity of their sin did not excuse sinners from blame. Since their inability was unwillingness, the greater their inability - that is, the stronger their disinclination - the more culpable they were. Yet their voluntary unwillingness to be holy was so fixed, so intransigent, so obdurate,

${ }^{6}$ Jonathan Edwards, Freedom of the Will, ed. Paul Ramsey (1754; rpt. New Haven: Yale Univ. Press, 1957), 431, 163, 156, 156-57, 159.

${ }^{7}$ Connecticut Evangelical Magazine, 4 (1803-1804), 285. 
that only God's free grace was powerful enough to change it. By showing that human behavior could be voluntary but still necessary, Edwards was able to prove that sinners were at once accountable moral agents and depraved creatures desperately in need of God's sovereign grace.

Samuel Hopkins and the other New Divinity preachers made Edwards's distinction between moral and natural necessity the shibboleth of their tribe. Yet they also slightly modified his interpretation of free agency. Instead of describing the liberty requisite to accountable agency as being a person's power to do as he pleased, the Hopkinsians represented it as a person's power to be voluntary in his willing. By "internalizing" Edwards's definition of liberty, they more firmly secured free agency. "Every exercise of the will in choosing or refusing is the exercise of freedom," asserted Samuel Hopkins, "and it is impossible for a man to will and choose without exercising moral liberty." ${ }^{8}$ Yet the internalization also meant that Edwards's disciples had to abandon his relatively unified model of psychology. Rather than saying that man was free, they said that the will or heart was free. In effect, they moved the battleground between moral and natural necessity from the frontier where the mind touched the physical world into the interior of the mind or soul itself. No longer just a border struggle with the corporeal, the problem of free agency also became a civil war between the faculties of the mind.

Since the will was where the voluntary preferences and choices occurred, it was the only voluntary and therefore the only moral faculty in the human soul. Seating moral qualities exclusively in the will meant, of course, that all other powers and capacities of the soul, including understanding and conscience, were natural rather than moral in character. It followed that the damage resulting from the Fall touched only the heart. If any other power or capacity of the soul had sustained injury, the sinner's inability to be holy would be excusable because it would be natural and not exclusively voluntary. New Divinity ministers would not admit that "human depravity lies in the least degree, in any real or imaginary destruction" of the intellect because they held depravity to be a "moral, and not a natural, disorder." Hence, they confined depravity to the will and affirmed that "the Undstdg. of Adam after his Fall was as good, \& equal to what it was in a State of Innocency." 10

In this matter, the Hopkinsians clashed with the Old Calvinists, who maintained that depravity afflicted not just the heart or will but all faculties,

${ }^{8}$ Frank Hugh Foster, "The Eschatology of the New England Divines," Bibliotheca Sacra, 43 (1886), 717.

${ }^{9}$ Ebenezer Bradford, Strictures on the Remarks of Dr. Samuel Langdon, on the Leading Sentiments in the Rev. Dr. Hopkins' System of Doctrines (Boston: I. Thomas and E. T. Andrews, 1794), 18.

${ }^{10}$ The quote is a critical comment by Ezra Stiles, taken from his Extracts from the Itineraries and Other Miscellanies of Ezra Stiles, D.D., LL.D., 1755-1794, ed. Franklin Bowditch Dexter (New Haven: Yale Univ. Press, 1916), 364, 412. 
including the understanding. As intellectualists, the Old Calvinists criticized their opponents for inflating the importance of the will by making it the governing and only moral faculty. It seemed to them that if the will were not under "the direction and government of the understanding," man was no longer a "rational and moral agent." "Old Calvinists believed that man was a moral agent because he was a cause by counsel whose understanding judged the good according to the motives presented to it and whose will then moved the soul to embrace that good. Hence Old Calvinists had two objections to the New Divinity scheme. First, in denying that moral concerns had anything to do with the understanding, the scheme subverted man's agency as a rational creature, in effect reducing men to animals and making God the author of sin. From this perspective, the Hopkinsians appeared to be hyperCalvinists. Second, in asserting that sin was nothing more than voluntary disinclination or unwillingness, the scheme implied that a gracious change was not needed for salvation. From this perspective, the New Divinity ministers appeared to be Arminians. ${ }^{12}$

For their part, the Hopkinsians argued that the Old Calvinists placed the sinner under an excusable, natural inability to perform his duty. By denying that sin was disinclination and by maintaining that the natural faculty of the understanding was depraved, the Old Calvinists burdened the sinner with "a cannot, independent of a will not." ${ }^{13}$ Yet it was impossible, said Samuel Hopkins, to make a person feel blameworthy or accountable for a "cannot." The consequence of the Old Calvinist doctrine was to cast all the blame for sin back on Adam, which was a notion "most sweet to many a corrupt heart." ${ }^{14}$ The New Divinity preachers warned that this kind of Calvinism would drive the religious folk to Arminianism and leave only the vicious behind to fill the churches.

Since they had different explanations of depravity, New Divinity and Old Calvinist ministers naturally had different explanations of how God went about saving sinners. Because the Old Calvinists assumed that sinfulness was not simply the total depravity of the heart but rather the universal depravity of all the faculties, they contended that there had to be a divine operation on both the intellect and the will. First the Spirit illuminated the understanding with a divine light, which enabled the person to see Christ as a suitable and all-sufficient Savior. This enlightenment was not by mere moral suasion.

\footnotetext{
"Samuel Langdon, Remarks on the Leading Sentiments in the Rev'd Dr. Hopkins' System of Doctrines (Exeter, N.H.: Henry Ranlet, 1794), 24. My argument here has been greatly influenced by Norman S. Fiering's "Will and Intellect in the New England Mind," William and Mary Quarterly, 29 (1972), 515-58, which suggests that the divisions among Calvinists during the Great Awakening continued earlier divisions between Puritan intellectualists and voluntarists.

${ }^{12}$ Moses Hemmenway, Remarks on the Rev. Mr. Hopkins's Answer to a Tract Intitled "A Vindication of the Power, Obligation and Encouragement of the Unregenerate to Attend the Means of Grace," \&c. (Boston: J. Kneeland, 1774), 137.

${ }^{13}$ Hopkins, Works, I, 509.

${ }^{14}$ Ibid., III, 299.
} 
Sinners did not regenerate themselves simply by listening to ministers preach the Word. The Spirit had to work internally with the truth, quickening it with an efficacious influence. After presenting the Savior in a proper light to the understanding, the Spirit renovated the will by inclining it to "desire and embrace that which the Understanding judgeth to be good." 15

Instead of the term "regeneration," Old Calvinists preferred "effectual calling," the phrase sanctioned by the Westminster Confession. Calling implied "inviting, and effectually persuading the sinners," so it left room for the play of the human understanding in the great change. ${ }^{16}$ Because Old Calvinists explained effectual calling as both an enlightenment of the understanding and a renovation of the will, they placed great importance on the means of grace. Since the Spirit used the means when it quickened the truth, the sinner's hope lay in attending upon them. There was further encouragement for sinners in the fact that the understanding, unlike the will, was not a disjunctive faculty. True, there was no real faith until the Spirit invigorated the Word, but on the other hand, the knowledge of truth might grow so gradually that it would be difficult to determine "at what point of time the principle of spiritual life was first infused." ${ }^{17}$ Moreover, there was abundant reason to conclude that those who strove would "receive further influences and assistances ... whereby they may become more and more prepared for the reception and exercise of the divine life, and so advance gradually towards the kingdom of God."18

Since there was a higher probability of mercy for the diligent, reformed sinner than for the indifferent, secure sinner, it was obviously a duty to be diligent and reformed. Sinners had the option to use or abuse the advantages presented them by common grace. They could attend public worship or guzzle in the tavern. Who could doubt which was better? Old Calvinists used the distinction between reformed and profligate sinners to argue that there were commanded duties that the unregenerate could perform acceptably before they received saving grace. Even though such unregenerate duties were not holy, even though they were selfish and misguided attempts to buy salvation, there was "a less degree of true moral evil in the conscientious performance of them, than in the contemptuous neglect of them."19

The best actions of the unregenerate were good in some respects, though

\footnotetext{
${ }^{15}$ Thomas Foxcroft, Like precious Faith obtained, through the Righteousness of our God and Saviour, by all the true Servants of Christ (Boston: Green and Russell, 1756), 31.

${ }^{16}$ Ezra Stiles Ely, A Contrast between Calvinism and Hopkinsianism (New York: S. Whiting, 1811), 128.

${ }^{17}$ Hemmenway, Seven Sermons, 162.

${ }^{18}$ Ibid., 106.

${ }^{19} \mathrm{Jedidiah}$ Mills, An Inquiry concerning the State of the Unregenerate under the Gospel (New Haven: B. Mecom, 1767), 101.
} 
not as good as they should be. A reformed sinner was like a child who sullenly obeyed his father's order to go to school. The father had not commanded the sulking - indeed, he hated it - but the child did better to go in a snit than not at all. Besides, the child who went crankily might eventually go cheerfully, but only if he continued to go. To a certain extent, the Old Calvinist position on unregenerate doings blurred the line between sinners and saints by declaring that the former could perform some acceptable duties. Although not Arminians, the Old Calvinists flirted with preparationism because they feared that if sinners were told that they could do no duty, they would do nothing at all. Old Calvinists sought to insure that the unregenerate, instead of being as bad as they might be, might be as good as they could be while awaiting God's grace..$^{20}$

The New Divinity ministers demanded not only that God's disobedient children go to school but that they go with smiles on their faces. Samuel Hopkins and company had a very different explanation of regeneration. Assuming that the heart or will was the only seat of depravity, they concluded that that faculty alone needed renovation. According to them, regeneration was a divine operation that turned the heart so that it loved and chose holiness. The will was a disjunctive faculty: it chose either sinfulness or holiness. Before regeneration it chose the former; after regeneration, the latter. Thus, there was an essential difference between the regenerate and the unregenerate. Hopkinsians had no room in their system for any vague, neutral status that was better than profanity but not quite so good as piety. Sinners performed no partial good or acceptable duty when they busied themselves with the means of grace. True, they enlightened their understandings with doctrinal truths, but the understanding was a natural faculty, not a moral one, so no amount of intellectual light could make a sinner holy. So long as he remained unconverted, an enlightened, Bible-reading sinner was no better than an ax-murderer. ${ }^{21}$

\footnotetext{
${ }^{20}$ It is important to stress that preaching "preparationism" did not make the Old Calvinists Arminians, or even crypto-Arminians. If anything, the aim of their doctrine was to guarantee moral behavior without succumbing to the Arminian error. Old Calvinists saw themselves as mediating between the Arminians, who made "too much of the sinner's seeking to God, in the diligent use of the means, as though there was in it something that is holy and spiritual," and the hyper-Calvinists, who made "too little of it, as tho' because it was not holy, or connected with promises; therefore it was quite nothing at all." See Mills, Inquiry, 73n.

${ }^{21}$ The New Divinity position is set forth in the following places: Hopkins, Works, I, 367-69; III, 217; Bradford, Strictures on the Remarks, 25; Nathan Strong, Sermons on Various Subjects, Doctrinal, Experimental and Practical (Hartford: Oliver D. and I. Cooke, 1798-1800), I, 130; Charles Backus, The Scripture Doctrine of Regeneration Considered, in Six Discourses (Hartford: Hudson and Goodwin, 1800), 21-22; Joseph Bellamy. The Works of Joseph Bellamy, D.D., ed. Tryon Edwards (Boston: Doctrinal Tract and Book Society, 1850), I, 49; Jonathan Edwards, Jr., The Works of Jonathan Edwards, D.D., ed. Tryon Edwards (Andover, Mass.: Allen, Morrill and Wardwell, 1842), I, 481-92.
} 
In the opinion of the New Divinity ministers, the Old Calvinist position was untenable. Hopkinsians alleged that the Old Calvinist emphasis on the illumination of the understanding was a thinly disguised Arminianism. If truth turned a person from sin to holiness, depravity was only misunderstanding or intellectual error, for which the remedy was not divine regeneration but better information. On this supposition, Hopkins observed, the most depraved sinner needed nothing for conversion "but that light and conviction of conscience which shall bring these things into clear view." ${ }^{22}$ Nor need this light necessarily come from God, whose only advantage over an eloquent minister or a nagging spouse was that he could "use arguments with more dexterity." ${ }^{23}$ If regeneration was illumination, conversion was, as admitted Arminians professed it to be, a matter of moral suasion and self-improvement.

Of course, when irritated Old Calvinists pointed out that a divine illumination involved more than just persuasive arguments, the Hopkinsians reviled them as antinomians. If the notion of some kind of special divine illumination meant anything at all, it had to mean that the understanding needed some alteration before the sinner could become holy. Yet that implied a natural inability - an implication that "men by nature have not sufficient capacity or faculty of understanding to know their duty." ${ }^{24}$ As regeneration would then be equivalent to giving an idiot his reason by a miracle, Hopkinsians challenged those "that hold to regeneration by light . . . to show how men are wholly to blame for continuing in a state of unregeneracy, or that this is any crime at all." 25

Similarly indefensible was the Old Calvinist position on unregenerate doings. If the Old Calvinists asserted that sinners who used the means of grace did some acceptable duty that earned them salvation, they slid into the Arminian ditch. In effect, they compounded with sinners by conceding that the unconverted differed only in degree from the converted. On the other hand, if Old Calvinists insisted on the gap between preparatory activity and effectual calling, they seemed guilty of encouraging an antinomian passivity. In effect, they told sinners that they could only come to the side of the healing pool and lie around waiting in the hope of drowning in a flash flood of divine grace-waiting, that is, until the Spirit operated with power on the means of grace.

The grave danger that the Hopkinsians detected in the Old Calvinist theology was its unevangelical tendency. Telling a sinner that he could and

${ }^{22}$ Hopkins, Works, III, 103.

${ }^{23}$ Nathanael Whitaker, Two Sermons: On the Doctrine of Reconciliation (Salem, Mass.: Samuel Hall, 1770), 71-72.

${ }^{24}$ Edwards, Jr., Works, II, 111.

${ }^{25}$ Hopkins, Works, III, 107. 
should perform some partial duties while still remaining a sinner implied that he lay under "an inability to repent and embrace the gospel, which does, in some degree at least, excuse him from not repenting immediately." ${ }^{26}$ The Old Calvinist notion of unregenerate duties encouraged complacency in sinners. It gave them ease short of Christ. It permitted them to remain sinners, while they attended the means of grace and pretended to wait for God's time.

New Divinity ministers demolished this cozy refuge by denying that unregenerate doings were in any way acceptable. Indeed, these theologians sometimes argued that the sinner grew worse under means because he sinned against greater light: his heart continued impenitent even as his intellect was stocked with more knowledge and truth. ${ }^{27}$ By disclaiming the value of the best actions of the unregenerate, Hopkinsians exposed themselves to the charge of being hyper-Calvinists, a charge that has tarnished their reputation from the eighteenth to the twentieth century. Of course, New Divinity ministers did not confiscate the Bibles of their unconverted parishioners. The Hopkinsian preachers did not tell sinners not to use the means of grace, but neither did they tell them that it was all right to use the means sinfully. Sinners who sowed tares should not expect to harvest anything but tares. Nor should they presume that sowing tares relieved them of the obligation to sow wheat.

The Hopkinsians could deny the value of unregenerate doings because they had so fully established the natural ability of sinners to repent and be holy. Since the unregenerate were under no natural necessity to sin, and since the only obstacle to their acceptable obedience was their voluntary unwillingness to obey, they should be pressed to immediate repentance. No unregenerate doings could possibly be acceptable because none came up to the true gospel duty, which God commanded and which the sinner had the natural ability to perform.

The problem with Old Calvinism was that it soothed and settled people in their status as sinners by giving them the idea that "the use of means is the whole duty to which they are now obligated." ${ }^{28}$ The New Divinity renunciation of unregenerate doings was (and still is) criticized for pulling the rug from under human activity in the process of conversion, but in fact the intention was quite the opposite. Hopkinsians alleged that it was the Old Calvinists who impugned human ability: that was why Old Calvinist preachers permitted the sinner to piddle his life away in an unavailing round of external duties. The Hopkinsians, on the other hand, could urge sinners "to commence christians immediately, and without delay" precisely because

${ }^{26}$ Ibid., I, 502; Joseph Washburn, Sermons on Practical Subjects (Hartford: Lincoln and Gleason, 1807), 309.

${ }^{27}$ Hopkins, Works, III, 263.

${ }^{28}$ Edwards, Jr., Works, II, 113-14. 
they believed that sinners had the natural ability to cease sinning whenever they chose to do so. ${ }^{29}$ New Divinity preaching was vigorously evangelical; its constant refrain was the demand for immediate repentance.

New Divinity theology was a response to the complaints of Arminians that Calvinism subverted people's sense of moral accountability. Hopkinsians sought to fashion a more defensible Calvinism, one that securely established moral agency without surrendering the characteristic Calvinist doctrines of divine sovereignty. Their solution to the problem enabled them to assume extreme positions on both freedom and necessity. They came into conflict with the Old Calvinists because the latter's doctrines seemed to leave Calvinism too vulnerable to the Arminian attack: Old Calvinism, when it remained Calvinistic, seemed dangerously antinomian.

Hopkinsians perceived this tendency as particularly evident in the Old Calvinist explanation of justifying faith. Justification was the divine action by which God ceased to consider a believer as being under the condemnation of the law. According to Calvinist theology, a person who was united to Christ by faith had the benefits of Christ's righteousness imputed to him. It was for this imputed righteousness that God justified him. Then, after justification changed the person's legal status, sanctification changed the person himself. ${ }^{30}$

The root of the difference between the Old Calvinists' and the Hopkinsians' interpretations of justification lay in their dissimilar theories of human psychology. Old Calvinists defined a moral agent as a creature whose will moved him according to the dictates of his understanding. Hence, when Old Calvinists described the act of justifying faith, they characterized it as a powerful belief in the mercy of God promised through Christ, a belief that moved the will to embrace that promise as the greatest good.

To Hopkinsians, this definition of saving faith seemed to imply a selfish kind of religion. First the understanding perceived the value of Christ as a mediator for sinners, and only then did the will choose to accept Christ as Savior. Hopkinsians feared that if the Old Calvinists made saving faith into a decision to come to Christ for life, they were not far from the antinomians' notion of "faith of assurance," which was an individual's unswerving belief

${ }^{29}$ Massachusetts Missionary Magazine, 1 (1803-1804), 260. This periodical was strongly Hopkinsian.

${ }^{30}$ The best account of the Puritan explanation of conversion is in William K. B. Stoever, " $A$ Faire and Easie Way to Heaven": Covenant Theology and Antinomianism in Early Massachusetts (Middletown, Conn.: Wesleyan Univ. Press, 1978). 
that Christ would save him. Although New Divinity ministers considered selfishness to be the essence of sin, Old Calvinists saw no reason to set holiness at odds with a desire for salvation. Old Calvinists assumed that since faith was a belief in God's mercy to sinners, there was no particular cause to rebuke people's natural self-love as sinful or selfish. Once the understanding was enlightened in effectual calling, it was entirely appropriate that self-love direct the believer back to God. ${ }^{31}$

As Hopkinsians began to think about it, they concluded that the Old Calvinists' morphology of conversion was wrong. The notion that faith (or intellectual belief) preceded, and was the ground of, holy love of God resulted in an unacceptably selfish and antinomian type of religion. Such a notion supposed that "a sinner is pardoned, and has a covenant title to eternal life, while unrenewed, as well as while impenitent." ${ }^{32}$ There was then no need for a change of heart; the unregenerate did not have to stop loving sin to be saved. After all, it required no change of heart in a sinner to love a God who proposed to save him from hell. The greatest enemy to God could do as much, just as a murderer, without ever repenting his crime, could love the judge who set him free. The Old Calvinists' doctrine of saving faith seemed unavoidably to weaken the authority of the moral law.

The New Divinity ministers, who believed that the will was the only moral faculty, could offer a description of justification that did not undermine the law. They began with the assumption that regeneration changed the heart or will from a love of sinfulness to a love of holiness. Since regeneration preceded justification, this meant that some holy volition or love preceded pardon. In saying this, the Hopkinsians began to move beyond Puritan standards, for they were asserting not merely that people performed a condition or qualification for justification (i.e., an act of faith) but that that performance was an act of personal, inherent holiness. The logic of their theory of the will eventually led the New Divinity theologians to alter the Puritans' normal order or morphology of conversion. Only after the regenerated heart exercised love of God could a person unselfishly believe in Christ unto salvation. Hence, the Hopkinsians rearranged the stages of conversion into the following order: regeneration, love of God, evangelical repentance, faith, justification, adoption, sanctification, and glorification. In this way they insured that saints would love God for what he was rather than out of gratitude for pardon.

${ }^{31}$ See William Hart, Brief Remarks on a Number of False Propositions, and Dangerous Errors, which are Spreading in the Country (New London, Conn.: Timothy Green, 1769), 58; and Ely, $A$ Contrast, 219-20.

${ }^{32}$ John Smalley, Sermons, on Various Subjects, Doctrinal and Practical (Middletown, Conn.: Hart and Lincoln, 1814), 377. 
The Old Calvinists, who believed that justifying faith must precede holy exercises, protested this new ordering. "If a man may be regenerate \& holy some Minutes and hours before the Exercise of Faith," they reasoned, why might he not "be months \&c. and even regenerated and go to hell at last?" 33 The Hopkinsians ignored this possibility because their principal concern was to demonstrate that there had to be inherent holiness before pardon. Nathanael Emmons, the most unflinching of the theological school, even went so far as to proclaim that "sanctification is before justification and the only proper evidence of it." ${ }^{34}$

The point was to eliminate any vestiges of antinomianism from Calvinism by showing that holiness was as much required under the gospel as under the law. The Old Calvinist order of conversion seemed to cheapen the law by implying that Christ came to relieve sinners from its demands. If people were justified without holiness, they were justified as sinners; but to justify sinners was to void the law. By requiring an inherent holiness before justification, the New Divinity theologians established the honor of the law and the accountability of sinners under it, whereas "those who place faith before love and repentance, make all religion selfish." ${ }^{35}$

The Hopkinsians were careful to stipulate that people were not justified for their inherent holiness. For one thing, personal holiness could not atone for an individual's past sins. Holiness of heart did not merit but only received a salvation merited by Christ. These theologians were not Arminians. Still, they were able to repel many of the Arminian attacks on Calvinism by showing that love came before justification, holy acts before the title to salvation, and the law before the gospel.

The phrase "willing to be damned" has haunted New Divinity theology from the beginning. Critics have always pointed to it as the most preposterous article of an exceedingly preposterous creed. The idea makes sense, though, when seen in terms of the Hopkinsian explanation of conversion. The Old Calvinists, who placed holy love after faith and justification, implied that God pardoned sinners who did not love him. New Divinity theologians, who saw regeneration as a change of heart and who believed that love preceded justification, assumed that sinners must love God before he pardoned them. Nathanael Emmons drew the conclusion: "If God does not love sinners before they love him, then they must love him, while they know

${ }^{33}$ Stiles, Literary Diary, I, 139; Stiles, Itineraries, 472-73.

${ }^{34}$ Nathanael Emmons, The Works of Nathanael Emmons, D.D., ed. Jacob Ide (Boston: Crocker and Brewster, 1842), V, 163.

${ }^{35}$ Ibid.; also see Bellamy, Works, II, 209n, 222; John Smalley, Sermons, on a Number of Connected Subjects (Hartford, Conn.: Lincoln and Gleason, 1803), 344-45; and Jacob Catlin, $A$ Compendium of the System of Divine Truth, 2nd ed. (Middletown, Conn.: E. and H. Clark, 1826), 152-53. 
that he hates them, and is disposed to punish them for ever." ${ }^{36}$ In short, they must love a damning God.

Hopkinsians declared that the regenerate must love God and the law before they could exercise faith, which was love of Christ and the gospel. The love of the law, known as evangelical repentance and experienced as unconditional submission, was the very opposite of the selfish concern for personal salvation permitted by the doctrines of the Old Calvinists and the antinomians. The regenerate heart loved the law because the law punished sin. Since a regenerate person delighted in the application of the law to others, he perforce delighted in the application of it to himself. The New Divinity convert would not cease to approve of the law even if he believed "that God designed, for his own glory and the general good, to cast him into endless destruction." ${ }^{37}$

The idea of unconditional submission carried with it a fundamental irony that relieved it of much of its apparent harshness. As this love of the law was a regenerate exercise, those who performed it would never feel the torments of hell. A willingness to be damned was not a habitual exercise of the saint; rather, it was a misapprehension arising out of an initial failure to realize that regeneration had occurred. Since a person "cannot know that he loves God till he has this disposition, which is necessarily implied in love to God, he does not know that it is not necessary for the glory of God that he should be damned." 38

The intention was to repudiate antinomianism by affirming that pardon followed holiness. More fundamentally, it was to demonstrate that the understanding lagged behind rather than dictated to the will. Consequently, the apprehension of the meaning of the change could only occur in the subsequent intellectual reflection upon the change. The antinomian faith of assurance, a selfish persuasion of one's own salvation, could never be the germ of true holiness.

The convert's innocent and cordial resignation to the divine will proved that his heart was fixed on God and not on his own desire for heaven. An un-self-conscious submission demonstrated that the convert was not "bribed into acquiescence." ${ }^{39}$ Yet most important, unconditional submission represented a commitment to the authority of the moral law during the experience of conversion. "The true believer," said Samuel Hopkins, "prizes holiness more than assurance, and is more concerned to obtain the former than the

\footnotetext{
${ }^{36}$ Emmons, Works, VI, 465.

${ }^{37}$ Hopkins, Works, I, 389.

${ }^{38}$ Ibid., III, 148.

${ }^{39}$ Gardiner Spring, Memoir of Samuel John Mills, 2nd ed. (New York: Saxton and Miles, 1842), 8.
} 
latter. ... Indeed, the true Christian ... is seeking more important objects and events than his own salvation." 40

Hopkinsians recognized that selfish religion overthrew the authority of the law. Selfish religion did not require holiness or obedience, either before or after justification. It set gospel against law and declared that Christ came into the world to mitigate the rigor of the requirements placed on sinners. Both Arminians and antinomians were guilty of preaching selfish religion. Both pandered to the sinner's desire to be saved without having to change his sinful heart. Both blurred the sharpness of the distinctions between saint and sinner, holiness and sinfulness, and good and evil.

New Divinity ministers wanted to preserve the authority of the law. They insisted that conversion not abate it by allowing sinners to be pardoned while their hearts remained wicked. Hopkinsians recognized that it was impossible to speak of an absolute difference between good and evil if human beings out of their own sinful natures were able to attain holiness, for that would mean that good was not the contradiction of evil but only an improved version of it. Only the necessity of a divine act transforming man from sin to holiness could insure the strict opposition of good and evil that moral order seemed to require. On the other hand, if sinners had no ability of their own to attain holiness, it was unfair to require it of them, and they were not accountable for their sin. If sinners lacked ability, the absolute distinction between good and evil was fundamentally irrelevant to their lives, for mankind did not live in a state of probation. In this case, as much as the other, moral order seemed impossible. The New Divinity theology allowed ministers to thread a path between these unacceptable alternatives. A gracious conversion sustained the absolute distinction between good and evil, but in a way that did not excuse sinners from responsibility for their sins. Thus, New Divinity theology provided a guarantee of the possibility of moral order in a society of sinners.

In the past two decades historians of eighteenth-century New England have told us much about what life was like in a society of sinners. Many of these historians have told a tale of disintegration and fragmentation. ${ }^{41}$ They

\footnotetext{
${ }^{40}$ Hopkins, Works, I, 533.

${ }^{41}$ Some of the relevant studies are the following: Paul Boyer and Stephen Nissenbaum, Salem Possessed: The Social Origins of Witchcraft (Cambridge: Harvard Univ. Press, 1974); Richard D. Brown, Modernization: The Transformation of American Life, 1600-1865 (New York: Hill and Wang, 1976); Richard L. Bushman, From Puritan to Yankee: Character and the Social Order in Connecticut, 1690-1795 (New York: W. W. Norton, 1970); Edward Cook, "Social Behavior and Changing Values in Dedham, Massachusetts, 1700-1775," William and Mary
} 
have described homogeneous, organic, cohesive communities which, though not collectivistic in organization, displayed a premodern, communal spirit. People who lived in these towns subordinated their individual self-interest to the good of the group, and rough parity of circumstances and prospects contributed to social harmony. Self-denial rested on a sense of shared fate. Consensual authority was possible because the community, through its town government, dispensed benefits to all as needed. The people farmed for a living, but they aimed no higher than a competence for themselves and security for their families. They valued goods according to standards of usefulness, as measured by the customary just price, and they traded for these goods in kind. They had little contact with the world outside their town, so their dealings were with people whom they knew well in all their social roles. There was a continuity to their experience, and their children's lives were like their own.

Then, historians have reported, came disruptive change. Population grew and towns found themselves without enough land for the rising generation. Once the common land had been distributed, children had to endure longer periods of dependency, at the end of which they received smaller benefits. Land shortage and soil depletion forced some youths into trades and others out of town. Control of the available land by some families cut off the avenue of opportunity for others. The result was social stratification-fixed distinctions within the community between rich and poor. These distinctions revealed themselves not only in the ownership of land but also in such things as the possession of luxury goods and the seating assignments in the church.

These changes began to corrode the townsfolk's sense of common purpose. Communities tasted the sourness of contention as town meetings became occasions of strident competition for access to privileges and limited resources. The fragmentation took literal form as towns divided into precincts and parishes to accommodate the needs and desires of particular groups. Instead of self-denial, people began to exhibit the more "modern" qualities of self-interest and individualism.

Farmers shifted from subsistence to commercial agriculture, but raising cattle and crops to sell for profit meant the end of customary prices and

Quarterly, 27 (1970), 546-80; Bruce C. Daniels, The Connecticut Town: Growth and Development, 1635-1790 (Middletown, Conn.: Wesleyan Univ. Press, 1979); Charles S. Grant, Democracy in the Connecticut Frontier Town of Kent (New York: Columbia Univ. Press, 1961); Philip J. Greven, Jr., Four Generations: Population, Land, and Family in Colonial Andover, Massachusetts (Ithaca: Cornell Univ. Press, 1970); Robert A. Gross, The Minutemen and their World (New York: Hill and Wang, 1976); Kenneth A. Lockridge, A New England Town, The First Hundred Years: Dedham, Massachusetts, 1636-1736 (New York: W. W. Norton, 1970); and Patricia J. Tracy, Jonathan Edwards, Pastor: Religion and Society in Eighteenth-Century Northampton (New York: Hill and Wang, 1980). 
barter exchange. Entrance into a market economy required that the value of goods be set in money, for money was divisible and thus capable of adjusting to changes in supply and demand. The commercial system replaced use valuation with exchange valuation, thus substituting flexible prices for just ones. Flexible prices meant competition and competition meant social atomization, as individuals pursued their own interests. Seeking prosperity instead of merely a competence, people took risks to maximize their profits, for they no longer had any standard of objective value except money.

The competition stimulated by the market economy subverted the basis for consensual authority. Individuals brooked no restraints of their pursuit of self-interest. They insisted on the importance of personal liberty, and the legal system obliged them by changing from standards of prescription to ones of proscription, from enjoining duties to prohibiting crimes. As people grew independent of communal values, their relations with others became contractual and impersonal, shaped by competition, calculation, and selfassertion. The individual stood isolated, sharply defined against others.

These historians have not told a cheery story. Recently, however, other historians have begun to reexamine the process of social change in New England..$^{42}$ They have noted that modernization involves not just a change in the economic structure of society but also a cultural change to a new mentality that values calculation and self-interest. They have argued that people had to learn to be individualistic. New Englanders who did not possess this modern mentality felt the market economy and its competitive, entrepreneurial behavior to be an alien and dislocating intrusion into their lives. This second group of historians accordingly has stressed the resistance that New Englanders offered to change: their reluctance to enter the commercial system, their continued commitment to consensus, their disinclination to exploit opportunities to the fullest. These historians have pointed to the cultural continuities in architecture, agriculture, crafts, folk tales, and songs. They have remarked on the lengths to which New Englanders went to preserve their stable, conservative, rural communities. They have noted, for example, that when land grew short, people tried to keep the community's

\footnotetext{
${ }^{42}$ Some of the relevant studies are the following: Christopher Clark, "Household Economy, Market Exchange and the Rise of Capitalism in the Connecticut Valley, 1800-1860," Journal of Social History, 13 (1979), 169-89; James A. Henretta, "Families and Farms: Mentalité in Pre-Industrial America," William and Mary Quarterly, 35 (1978), 3-32; Christopher M. Jedrey, The World of John Cleveland: Family and Community in Eighteenth-Century New England (New York: W. W. Norton, 1979); John J. Waters, Jr., "Patrimony, Succession, and Social Stability: Guilford, Connecticut in the Eighteenth Century," Perspectives in American History, 10 (1976), 131-60; and Michael Zuckerman, Peaceable Kingdoms: New England Towns in the Eighteenth Century (New York: Knopf, 1970). An important work that studies New York rather than New England is William J. McLaughlin, "Dutch Rural New York: Community, Economy, and Family in Colonial Flatbush," Diss. Columbia Univ. 1981.
} 
distribution of wealth relatively stable by leaving their farms to one child and establishing the others in new towns on the frontier. As long as a premodern mentality remained strong, social change met resistance.

These two interpretations of New England social history might not be as far apart as they at first seem. Both recognize that before New England society could become fully modern there had to be a restructuring of consciousness and cultural values. The second interpretation stresses the resistance to change and the persistence of the older attitudes. Yet the first interpretation implies much the same thing in its frequent references to the tension between individualistic behavior and communitarian values, an anxiety-inducing tension that is seen as erupting in such diverse therapeutic explosions as witch hunts, ministerial dismissions, revivals, and even revolutionary wars.

Both interpretations imply that people change their values only reluctantly and at some cost. Both propose that from the perspective of older values, individualism seemed anarchical. They also suggest that changes in behavior required a change in people's knowledge about moral existence-a change, that is, in people's understanding of what was proper and improper, virtuous and vicious, good and evil. New Englanders needed a new set of values, a new ethic, a new theology, to fit them for a new kind of behavior.

The problem they faced was to convince themselves that self-interest and individualism would not inevitably produce a chaotic and lawless society. Only a confidence in the idea of self-interest could make it possible to conceptualize behavior in a new way. Consider, for example, the kind of impersonal relations arising out of the desire to turn a profit. In contractual transactions, people took risks by dealing with strangers. Yet the competitive nature of the market made these exchanges seem hostile rather than mutually beneficial. For these transactions to proceed with confidence, there had to be some certainty that individuals would keep their selfishness within limits and that they would honor their contracts even when it was no longer to their advantage to do so.

In short, individualism required certain generally accepted restraints on self-interest. Before rural New Englanders could experiment with individualistic behavior, they needed to believe that all self-interested individuals subscribed to universal rules about right and wrong, according to which competition could proceed in an orderly and predictable way. Those who were just entering a market economy wanted to know that there were absolute standards of right and wrong, and that the strangers with whom they dealt recognized those standards.

If New Englanders encountered the market economy with anxiety and trepidation, it is hardly surprising. There could be no guarantees that selfinterested individuals might not retail their rectitude as they did their cattle: hold it until the market was high, then dump it. After people grew accus- 
tomed to the ways of the market, they might relax their vigilance and admit that self-interest policed itself. Initially, however, only an explicit affirmation of the existence of absolute standards of virtue could embolden people to behave in new and rash ways. The new mentality of commercialism had to emerge out of the old mentality of communalism. New Englanders had to transform a sense of common purpose in a community into a sense of common allegiance to absolute and universal moral principles. Their ability to accomplish this feat helps explain why the region with the strongest communal tradition was to become renowned for its commercial sharpness. ${ }^{43}$

Theology is not peripheral to social experience. ${ }^{44}$ Taking the word in its largest sense, theology is the knowledge that people have of the universe they inhabit. By assigning meaning and value, theology delineates the kinds of experience available or possible to a people in a given society. It sets forth the assumptions and rules under which an activity is considered to have been done properly or improperly; that is, to be right or wrong. Thus, theology is one of the things that makes it possible for people to live together in societies.

Social experience must have meaning conferred upon it. Theology mediates between experience in the world and the understanding of that experience in the mind. The relation between theology and social experience is, however, neither simple nor unilinear; rather, it is reciprocal, allowing for a continuing, mutually influential dialogue. Theology and social experience strive for equilibrium, each moving to accommodate changes in the other, so that experience remains meaningful and the reality confronting people makes sense.

${ }^{43} \mathrm{My}$ thinking on these matters has been greatly influenced by the following works: Joyce Appleby, "Ideology and Theory: The Tension between Political and Economic Liberalism in Seventeenth-Century England," American Historical Review, 81 (1976), 499-15; Appleby, "Locke, Liberalism and the Natural Law of Money," Past and Present, no. 71 (May 1976), 43-69; Thomas Bender, Community and Social Change in America (New Brunswick: Rutgers Univ. Press, 1978); Sacvan Bercovitch, The Puritan Origins of the American Self (New Haven: Yale Univ. Press, 1975); J. E. Crowley, This Sheba, Self: The Conceptualization of Economic Life in Eighteenth-Century America (Baltimore: Johns Hopkins Univ. Press, 1974); Joseph R. Gusfield, Community: A Critical Response (New York: Harper and Row, 1975); Karen Lee Halttunen, "Confidence Men and Painted Women: The Problem of Hypocrisy in Sentimental America, 1830-1870," Diss. Yale Univ. 1979; Albert O. Hirschman, The Passions and the Interests: Political Arguments for Capitalism before Its Triumph (Princeton: Princeton Univ. Press, 1977); and Richard I. Rabinowitz, "Soul, Character, and Personality: The Transformation of Personal Religious Experience in New England, 1790-1860," Diss. Harvard Univ. 1977.

${ }^{44}$ The following four paragraphs summarize the interpretation found in Peter L. Berger and Thomas Luckmann, The Social Construction of Reality: A Treatise in the Sociology of Knowledge (Garden City, N.Y.: Doubleday, 1966). 
From one perspective, theology is an independently existing body of theory that proceeds according to its own logical inner dynamic of argument and counterargument. The resulting changes in theology, by revising the explanation of reality, open new possibilities for behavior in the world. A person encounters a world with the lines of meaning and value redrawn, and so he can act in different ways. When this happens, theological change has altered social experience. From another perspective, changes in social experience compel adjustments in theology. If theology failed to come to terms with social change, it would abrogate its responsibility to explain reality. People would feel anxiety as their behavior came to seem meaningless and anarchical instead of meaningful, predictable, and proper. Therefore, theology must change in response to alterations in social experience.

The question of which change comes first is perhaps unanswerable, for we always encounter the world in medias res. It is worth noting, though, that in its adjustments a theology always attempts to retain its integrity as a systematic body of theory. In other words, theologies try to remain consistent. What this means is that as much as possible people use the old and familiar to make sense of the new and unfamiliar. In one sense, this theological conservatism restrains or limits change, but in another sense it makes change tolerable and therefore possible.

Historians who have considered the social implications of New Divinity theology have generally concluded that it was a conservative, rural insurrection against transformations in the New England social order. ${ }^{45}$ An archaic theology of austere Calvinism, we have been told, appealed to the agricultural temperament. Hopkinsian ministers, many of them farm boys uprooted by demographic and economic changes, turned their resentment against an emerging acquisitive, individualistic style of behavior. The rural folk who filled their churches were receptive to a gospel dedicated to preserving the traditional social values of self-restraint and general concord.

To advance their social goals, the Hopkinsian ministers preached energetically on the need for sacrificing self-interest to the greater general good. By

\footnotetext{
${ }^{45}$ This interpretation is most fully set forth in Joseph Anthony Conforti, Samuel Hopkins and the New Divinity Movement: Calvinism, the Congregational Ministry, and Reform in New England between the Great Awakenings (Grand Rapids, Mich.: William B. Eerdmans, 1981). See also Stephen E. Berk, Calvinism versus Democracy: Timothy Dwight and the Origins of American Evangelical Orthodoxy (Hamden, Conn.: Archon Books, 1974); Richard D. Birdsall, "Ezra Stiles versus the New Divinity Men," American Quarterly, 17 (1965), 248-58; Birdsall, "The Second Great Awakening and the New England Social Order," Church History, 39 (1970), 345-64; Joseph A. Conforti, "Samuel Hopkins and the New Divinity: Theology, Ethics, and Social Reform in Eighteenth-Century New England," William and Mary Quarterly, 34 (1977), 572-89; Robert L. Ferm, A Colonial Pastor: Jonathan Edwards the Younger, 1745-1801 (Grand Rapids, Mich.: William B. Eerdmans, 1976); and Edmund S. Morgan, "The American Revolution considered as an Intellectual Movement," in Arthur M. Schlesinger, Jr. and Morton White, eds., Paths of American Thought (Boston: Houghton Mifflin, 1963).
} 
defining sin as selfishness and holiness as universal disinterested benevolence, the New Divinity preachers denied that there could be any acceptable self-love short of universal love. By refusing to draw a distinction between legitimate self-love and illegitimate selfishness, they rebuked all individualistic behavior as sinful. The demand that converts willingly submit to damnation for the glory of God is pointed to as the ultimate expression of the Hopkinsians' commitment to selflessness. Given this insistence that the individual subordinate his own interest to the general good, the New Divinity theology should be viewed as a resistance movement, retarding the arrival of an atomistic, egoistical commercial order.

The usual interpretation is not entirely correct. Hopkinsian theology was more than just a reactionary defense of the traditional social ethic against the threat of individualistic behavior. Instead, it contributed to the creation of a new mentality, one that permitted New Englanders to venture into market relations with something approaching confidence. This confidence required three things initially. First, there had to be an affirmation that there were universal and absolute standards of right and wrong. Second, there had to be a renunciation of all forms of self-interest that threatened to reduce the social order to anarchy. Third, there had to be a new way to conceive of self-interest so that it would seem legitimate, limited, and orderly. New Divinity theology met all three of these demands.

First, New Divinity theology upheld the absolute distinction between good and evil. Indeed, the principal goal of the Hopkinsians was the defense of the law against critics like the Arminians who charged that it was unfair. The New Divinity demonstrated that sinners were justly accountable under the law, even though they were necessarily and totally depraved. Devotion to the law led the Hopkinsians to deny the value of even the best actions of the unregenerate. The same devotion led them to propound an explanation of justification that guarded against antinomianism. The willingness to be damned, which was an integral part of every New Divinity conversion, was an overt, explicit, personal commitment to the authority of the divine law. Through their unconditional submission, converts internalized absolute and unqualified criteria of virtue and vice. The legalism of the New Divinity guaranteed that there would be no compromises with sinners before regeneration and no cheaper terms for saints after it. The belief in the existence of universal moral principles made it possible for rural New Englanders to take their first tentative steps into the market economy.

Second, the New Divinity theology condemned those varieties of selfinterest that threatened to produce anarchy by weakening the authority of the law. Hopkinsians exposed the antinomian implications of the Old Calvinistic explanation of justification. New Divinity theologians showed that a mercenary faith, which selfishly sought salvation and passively relied 
on Christ's imputed righteousness, threatened to cloud the difference between holiness and sin. In addition, Hopkinsians rebuked as dangerously antinomian the Old Calvinist notion that the unregenerate were able to perform some acceptable duties.

Old Calvinists disliked the stark distinction between regeneracy and unregeneracy because they feared that it would discourage moral behavior. They insisted that the sinner had some duties to discharge even though God had not yet converted him. Their concern was to show that there was a range of moral positions, and that it was better to have sinners behaving themselves for bad reasons than not to have them behaving themselves at all. Old Calvinists maintained that there could be a kind of secondary virtue arising from a self-interested use of the means which was, if not truly holy, at least useful for civic morality. This idea made eminent sense in traditional communities, where familiarity gave people a pretty good idea which of their neighbors were truly and inwardly virtuous and which were not. The idea made sense in urban, commercial centers as well, where more extensive experience with self-interested behavior made people less apprehensive of its anarchical potential and where, accordingly, they were less fussy about internal holiness so long as external morality was observed. Yet for rural folk just entering into impersonal, contractual market relations with strangers, the question of whether to trust a self-interested sinner might seem more problematic. What the New Divinity gave these people was a guarantee that the distinction between virtue and vice was not blurred but sharp. It promised them that there was no fuzziness in moral matters; there was no neutral or legitimate self-love standing somewhere between holiness and sin.

Finally, New Divinity theology made individualism possible by offering a nonantinomian concept of self-interest. The famous Hopkinsian definition of holiness as universal disinterested benevolence was more than just a protest against selfish behavior. New Divinity ministers demanded that benevolence be impartial and disinterested, not uninterested. Hence they did not condemn benevolence directed toward oneself. Samuel Hopkins observed that a "person who exercises disinterested good will to being in general must have a proper and proportionable regard to himself, as he belongs to being in general, and is included in it as a necessary part of it." In fact, a person had an obligation to exercise his benevolence where it would do the most good, especially toward those whose wants were most in his sight. Since every person knew his own needs best, "his disinterested, universal benevolence, will attend more to his own interest, and he will have more and stronger exercises of it, respecting his own circumstances and happiness, than those of others, all other things being equal." ${ }^{46}$

${ }^{46}$ Hopkins, Works, I, 240-41, 377-78. 
Thus, the doctrine of disinterested benevolence made it possible for an individual to treat his own interest abstractly. It allowed a person to pursue his self-interest by redefining it as a form of disinterested benevolence. In this way, Hopkinsianism offered a theoretical justification of self-interest to a people who wanted some reassurance that it would not lead to antinomianism and social anarchy. The idea of disinterested benevolence permitted individualism, but only after categorizing it as duty and after affirming that it did not overthrow the absolute distinction between virtue and vice. Behavior that in the past could only have been seen as selfish and sinful now could be viewed as acceptable and even holy.

New Divinity theology offered a kind of religious version of Adam Smith's idea that an Invisible Hand shaped the greatest general good out of individuals' seeking their own interests. Both Samuel Hopkins and Adam Smith provided a theoretical legitimation of individualism through the promise that limits and laws lurked behind (or within) the pursuit of self-interest. New Divinity theology reassured anxious New Englanders that there was a catch in the whirling ratchet of selfishness that would stop it from spinning inexorably into anarchy.

New Divinity ministers helped create a mentality fitting New Englanders for participation as individualistic entrepreneurs in a market economy. Their theology set forth the limits and boundaries that people needed when they began to look beyond their familiar surroundings. It helped transform New England from a cluster of covenanted communities to a conglomeration of converted individuals. It made individualism assimilable by squaring it with an absolutistic law. It smoothed the way for acquisitive and egocentric behavior, not through the cynical conclusion that society could survive the activities of sinful men, but through the optimistic promise that saints would respect limits. In sum, it gave rural New Englanders that "perfect law of liberty" which they might follow, secure in the Apostle's promise that if they did they would be blessed in their deeds. ${ }^{47 *}$

${ }^{47}$ James $1: 25$.

*Versions of this paper were presented at a colloquium sponsored by the Institute of Early American History and Culture, and at the December 1980 meeting of the American Society of Church History. I would like to thank the Institute of Early American History and Culture for its generous support. 